\title{
AN ATTEMPT AT EVALUATION OF THE REMNANT INFLUENCE ON THE OCCURRENCE OF SEISMIC PHENOMENA IN A ROOM-AND-PILLAR MINING SYSTEM WITH ROOF DEFLECTION
}

\author{
Karolina Adach-Pawelus, Jan Butra, Daniel PaWelus \\ Wrocław University of Science and Technology, Faculty of Geoengineering, \\ Mining and Geology, ul. Na Grobli 15, 50-421 Wrocław, \\ e-mail: karolina.adach@pwr.edu.pl,jan.butra@pwr.edu.pl,daniel.pawelus@pwr.edu.pl
}

\begin{abstract}
Experience gained until now underground mining worldwide and in Poland indicates that remnants may have an impact on the occurrence of seismic phenomena. Remnants are stress concentration sites encompassing both the deposit and the layers of rock mass located above and below the undisturbed rock. In the case where stresses in the remnant exceed its strength, it may collapse, and under unfavourable geomechanical conditions, stress-induced rockburst may occur. Remnants may also cause breaking of strong roof layers above their edges, which results in the occurrence of high-energy shocks (Salustowicz [30], Adach [3], Adach and Butra [4]).

This article presents the possibility of utilizing numerical modeling to evaluate the influence of remnant upon the occurrence of seismic phenomena. The results of numerical calculations performed for a model room-and-pillar mining system with roof deflection under the conditions of copper ore mines in the Legnica-Głogów Copper District (LGOM) are presented. Numerical calculations in a plane strain state were performed by means of Phase2 v. 8.0 software for the analyzed mining system in which remnant was left behind. The results of numerical modeling showed that sudden fracturing of roof layers above the mined out space may occur on the edge of the remnant. This may cause a shock with very high energy, and under the appropriate conditions, this may lead to the rockburst phenomenon.
\end{abstract}

Key words: remnant, numerical modeling, seismic phenomena, room and pillar mining system

\section{INTRODUCTION}

In underground mining, there are sometimes geological and mining situations that necessitate leaving behind remnants in the mining field. Remnants, in the form of small, irregular parcels, are usually separated in the case of: significant problems with maintaining roof stability, high rockburst risk, the occurrence of complex geological conditions and for random reasons (ore remnants), as well as for economic reasons (undisturbed rock remnants).

Observations in mines and analyses conducted in both hard coal mines (Salustowicz [30], Parysiewicz [28], Drzezla et al. [15], Goszcz [19], Nawrat and Jakubów [27], Chlebowski et al. [12], Burtan and Chlebowski [6], Kłeczek et al. [21], Setlak et al. [32]) as well as in copper mines in LGOM indicate a relationship between the occurrence of seismic shocks and rockbursts and the position of remnants and excavation edges (Butra et al. [7], Dębkowski et al. [14], Butra [9], Butra et al. [10], Adach [2]).

Leaving undisturbed rock remnants may have a negative impact on the risk of shocks and rockbursts in the mining field and may pose a threat to works performed in their vicinity. Remnants of the appropriate width made of rock prone to rockbursts become sites where stresses of high value are concentrated when strong layers are present in the roof and floor. When the strength of rock making up a remnant is exceeded, it may be crushed suddenly, followed by a stress-induced rockburst (Salustowicz [30], Parysiewicz [28], Goszcz [15], Chudek [13]). Fragments of undisturbed rock that are left behind may also cause a collapse of roof layers (resulting in the occurrence of high-energy shocks) (Salustowicz [30], [31]) or cause dynamic phenomena with a slip-based mechanism as a result of the activation of unstable zones in the roof above their edges (Goszcz [19], [20]).

This article presents the results of numerical simulations conducted for a room-and-pillar mining system with roof deflection. A remnant with a width of $40 \mathrm{~m}$ was simulated in this mining field. Numerical analyses where conducted in a plane strain state by means of Phase2 v. 8.0 software. Conducted numerical analyses demonstrated that sudden fracturing of roof layers above gob areas may occur on the edge of 
the remnant as a result of shear strength of these layers being exceeded. This may cause a shock with very high energy, and under the appropriate conditions, this may lead to the rockburst phenomenon.

\section{INFLUENCE OF REMNANTS ON THE ROCK MASS}

It was attempted to solve the problem of the influence of remnants on the surrounding rock mass with analytical methods. Salustowicz determined stress distribution in a remnant and its immediate surroundings [30], [31] based on the equation based on the pressure wave theory, among other things. This equation shows that, if a remnant has a certain width of $2 l$, then two areas of maximum stresses are present on its edges, at a certain distance $x_{m}$ from edges $K_{1}$ and $K_{2}$ (Fig. 1). As the dimensions (width) of the remnant decrease, stresses are superposed on its edges, and in the extreme situation, they are summed and reach very high values (Salustowicz [30], [31], Goszcz [19], Butra [9], Chudek [13]). When the remnant is appropriately narrow, maximum compression stresses are present at its center and amount to

$$
\sigma_{z}=-\left(2 \cdot \frac{2 k}{\sqrt{3}}+\frac{2 k}{\sqrt{3}} \cdot \frac{l}{h}\right)
$$

where

$l$ - half of pillar (remnant) width,

$h$ - half of remnant height,

$2 k$ - yield point.

The strength of a remnant largely depends on its size, namely, on the quotient of its width and height. A state of equilibrium is present in the compressed remnant until the average value of stresses exceeds the value resulting from the equation

$$
\sigma=2 \cdot \frac{2 k}{\sqrt{3}}+\frac{k}{\sqrt{3}} \cdot \frac{l}{h} .
$$

When the remnant strength is exceeded, it may be crushed and material may be displaced to the sides. In the case of wide remnants, critical stress will have a much greater value than for narrow remnants (Salustowicz [30]).

Salustowicz also provided an analytical method for determining stress values and distribution in the rock mass under a remnant. Due to the size and proportions of main stresses, the area of the rock mass under the remnant was divided into three zones (Fig. 1). In zone 1 , directly under the rock remnant, a stress state similar to hydrostatic is present, and the rock is in a pseudoplastic state. Zone 2 is characterized by the fact that normal stresses have a lower value than in zone 1 , however shear stresses reach their greatest values. When the strength of the material in this zone is exceeded, slips occur first (symptom of a plastic phase), followed by fractures and crevices. This is the zone of the greatest effort of the material, in which a brittle character of destruction is dominant. In zone 3, normal and shear stresses are lower than in zones 1 and 2, but still greater than original stresses. Its exterior boundary constitutes the boundary of the remnant action.

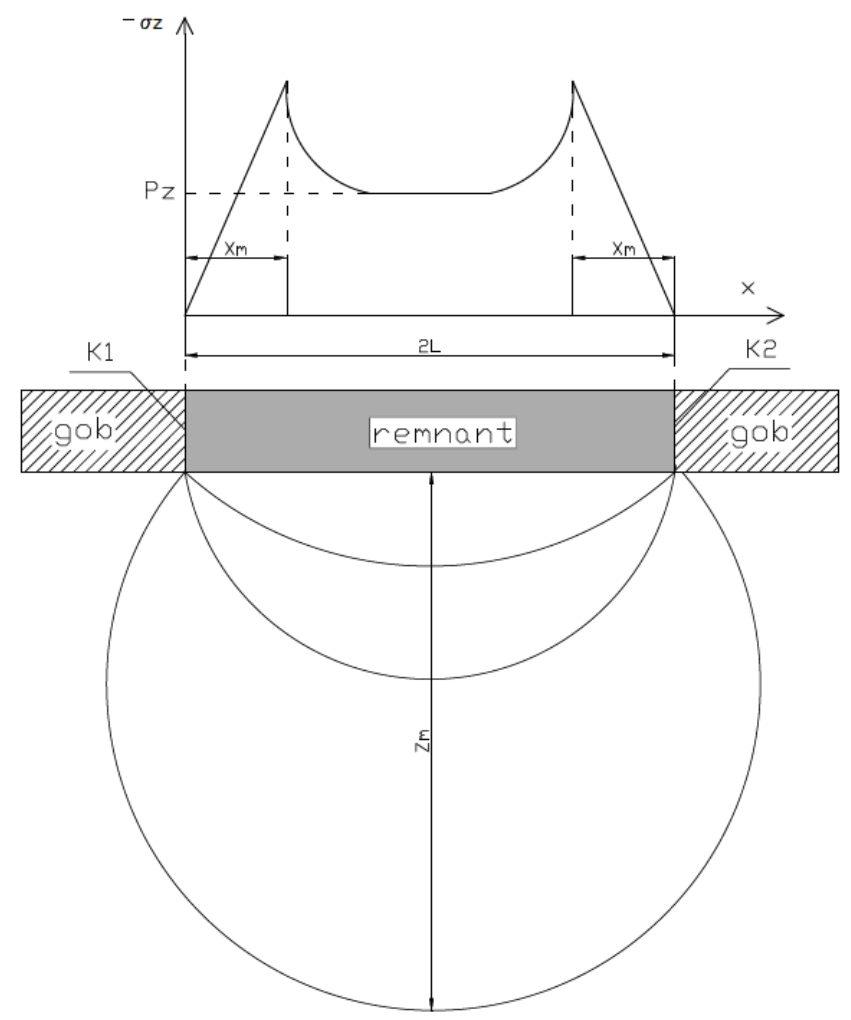

Fig. 1. Action of undisturbed remnant (based on Goszcz [19])

The influence of remnants on the surrounding rock mass was also analyzed on the basis of numerical methods by means of the NASTRAN package, which utilizes a spatially formulated finite element method (Dębkowski et al. [14], Butra and Pytel [8]), as well as in a plane strain state by means of FLAC (Dyczko et al. [18]) and Phase 2 software (Adach [1], Butra and Adach [11], Adach [3], Adach and Butra [4]).

Dynamic phenomena located in the vicinity of remnants (pillars) and various cases of sudden pillar destruction were studied on a large scale in gold ore mines in the Republic of South Africa. Fragments of undisturbed rock of various shapes and sizes were analyzed under diverse geological and mining condi- 
tions (Lenhardt and Hagan [23], Leach and Lenhardt [22], Lenhardt [24], Durrheim et al. [17], Durrheim et al. [16], Le Roux [25], Le Roux and Stacey [26]).

Based on observations in the Western Deep Levels - West Mine gold ore mine in RSA, Lenhardt and Hagan (1990) distinguished four destruction mechanisms that can generate dynamic phenomena in the vicinity of remaining undisturbed rock. They found out that relatively narrow pillars may undergo rupturing as a result of the loads acting on them. However, in the case of pillars of greater width, at a sufficiently high stress concentration, slip may occur on one or two shear planes, which are found under the edges of the pillar. This may cause sudden embedding (pushing) into the floor (Fig. 2).
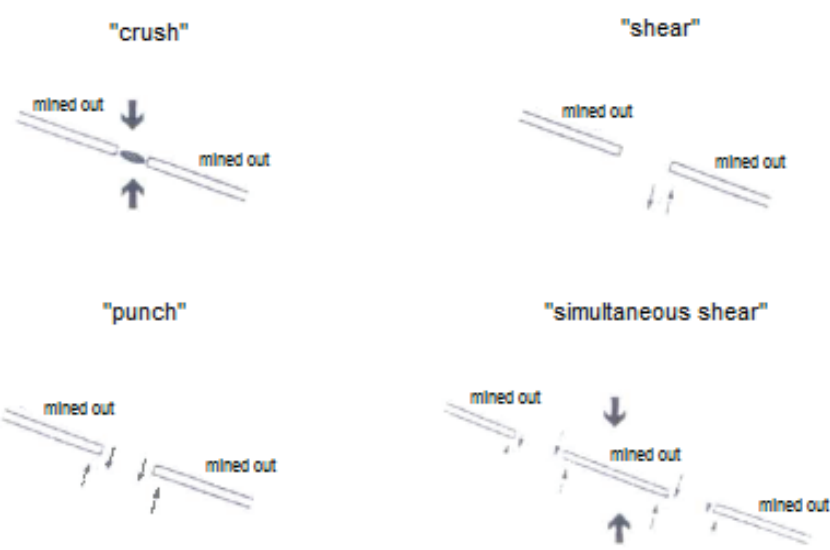

Fig. 2. Four mechanisms of seismic phenomena related to stabilizing pillars (Lenhardt and Hagan [23])

Leach and Lenhardt [22] determined that the magnitude of seismic phenomena in the vicinity of remaining parts of undisturbed rock does not depend on their width (within the limits from $20 \mathrm{~m}$ to $60 \mathrm{~m}$ ). Lenhardt [24] expanded this, explaining that the deciding factor affecting the quantity of the energy of dynamic phenomena in the vicinity of remaining undisturbed rock (stabilizing pillars) is the range of destruction along their edges, and this mechanism leaves a pillar's core intact and does not depend upon its width. He also acknowledged that the presence of shear stress concentrations on pillar edges should also be a significant parameter in pillar design.

Based on backward analysis of seismic phenomena in the vicinity of remnants in the Free State region in South Africa, Le Roux [25] stated that there is a strong correlation between the stress state considering the stress state inside remnants over the course of each seismic phenomenon. He proposed the RFI (Remnant Failure Index) criterion, based on the Mohr -Coulomb strength hypothesis to evaluate the stability of deposit remnants and their tendency to collapse suddenly in the Free State region (Le Roux [25], Le Roux and Stacey [26]).

Scientists are still searching for optimal methods to evaluate the stability of remnants and their action on the surrounding rock mass. They are attempting to identify the mechanisms initiating high-energy dynamic phenomena occurring near remnants as well as to develop effective methods to counteract rockburst risk.

\section{CHARACTERISTICS OF THE AREA OF RESEARCH}

Numerical modeling of the influence of a remnant on the occurrence of seismic phenomena in a roomand-pillar mining system with roof deflection was performed for geological and mining conditions present in one of the mining fields of copper mines in LGOM. The deposit in the analyzed area is at a depth of approximately $1000 \mathrm{~m}$ and is present in the lower part of the zechstein carbonaceous series and the roof of red rotliegend. It includes grey sandstone, copperbearing silty and dolomitic-silty shale as well as dark grey, streaked dolomite. The roof is made up of rock layers entering into the composition of the zechstein carbonaceous series. The direct floor is made up of grey sandstones of red rotliegend. The deposit span is

Table 1. Characteristics of modeled mining field

\begin{tabular}{|c|c|c|c|c|c|c|c|}
\hline $\begin{array}{c}\text { Depth } \\
\text { of deposit } \\
\text { (average) } \\
{[\mathrm{m}]}\end{array}$ & $\begin{array}{c}\text { Height } \\
\text { of mined part } \\
\text { of deposit } \\
{[\mathrm{m}]}\end{array}$ & $\begin{array}{c}\text { Front } \\
\text { length } \\
\text { (average) } \\
{[\mathrm{m}]}\end{array}$ & $\begin{array}{c}\text { Dimensions } \\
\text { of technological } \\
\text { pillars and } \\
\text { direction } \\
\text { of longer axis } \\
{[\mathrm{m}]}\end{array}$ & $\begin{array}{c}\text { Opening } \\
\text { of work } \\
\text { space }\end{array}$ & $\begin{array}{c}\text { Width } \\
\text { of excavations } \\
\text { during } \\
\text { splitting } \\
\text { phase } \\
{[\mathrm{m}]}\end{array}$ & $\begin{array}{c}\text { Method } \\
\text { of liquidation } \\
\text { mining } \\
\text { space }\end{array}$ & $\begin{array}{c}\text { Applied } \\
\text { mining } \\
\text { system }\end{array}$ \\
\hline 1000 & $2.0-2.8$ & $\sim 500$ & $\begin{array}{c}6 \times 8 \\
\text { perpendicular }\end{array}$ & $\begin{array}{c}\text { from } 4 \\
\text { to } 5 \text { belts }\end{array}$ & 6 & $\begin{array}{c}\text { roof deflection } \\
\text { with placement } \\
\text { of waste rock }\end{array}$ & $\begin{array}{c}\text { room-and-pillar } \\
\text { with roof } \\
\text { deflection }\end{array}$ \\
\hline
\end{tabular}


oriented in the NW-SE direction, and it dips $\left(2-3^{\circ}\right)$ toward the NE direction. The height of the mined part of the deposit amounts to $2.0-2.8 \mathrm{~m}$.

Mining of the deposit in the analyzed field was performed according to the room-and-pillar system with roof deflection. Technological pillars with basic dimensions of $6 \times 8 \mathrm{~m}$ were applied, situated perpendicularly to the line of the mining front. The width of the working space was generally 4 to 5 belts (Table 1). Due to the problems with maintaining the stability of the roof, a deposit remnant of approximately $40 \mathrm{~m}$ in width was separated. The mining field was characterized by a relatively high level of seismic activity. Its rockburst risk was classified as level III.

\section{ASSUMPTIONS OF NUMERICAL MODELING}

Numerical simulations were performed by means of Phase 2 v. 8.0 software, based on the finite element method. This software makes it possible to conduct numerical analyses in a tri-axial stress state and plane strain state. An elastic-plastic model with softening was accepted for the rock mass (roof and mined deposit). For the floor elastic model was used. It was assumed that the medium is homogeneous and isotropic. The Mohr-Coulomb strength criterion was applied, and according to this criterion, limit effort is described by the formula

$$
\sigma_{1}=\sigma_{3} \cdot \frac{1+\sin \phi}{1-\sin \phi}+\frac{2 c \cdot \cos \phi}{1-\sin \phi}
$$

where

$\sigma_{1}, \sigma_{3}-$ maximum and minimum stress at destruction,

$\phi$ - internal friction angle,

$c$ - cohesion.

The numerical model was a plate in which the rock strata making up the rock mass were accounted for (Fig. 3). The accepted structure of the rock mass resulted from a geological survey conducted in the region subject to analysis. The upper edge of the model was subject to vertical load representing the action of the overburden. It was assumed that a stress equal to $17.657 \mathrm{MPa}$ would be present at the level of the face's upper edge, which corresponds to the value of vertical stress determined for the analyzed region based on data from borehole S-294. The self-weight of rock layers was accounted for in calculations. No vertical displacements were set on the bottom edge of the plate, and no horizontal displacements were set on the plate's side edges. A finite element mesh consisting of 3-node triangular elements was applied. The element mesh was concentrated at the center of the plate in order to improve the accuracy of numerical simulations.

Calculations were performed step-by-step, simulating mining performed according to the room-andpillar system with parameters characteristic of the analyzed mining field (64 computational steps). The

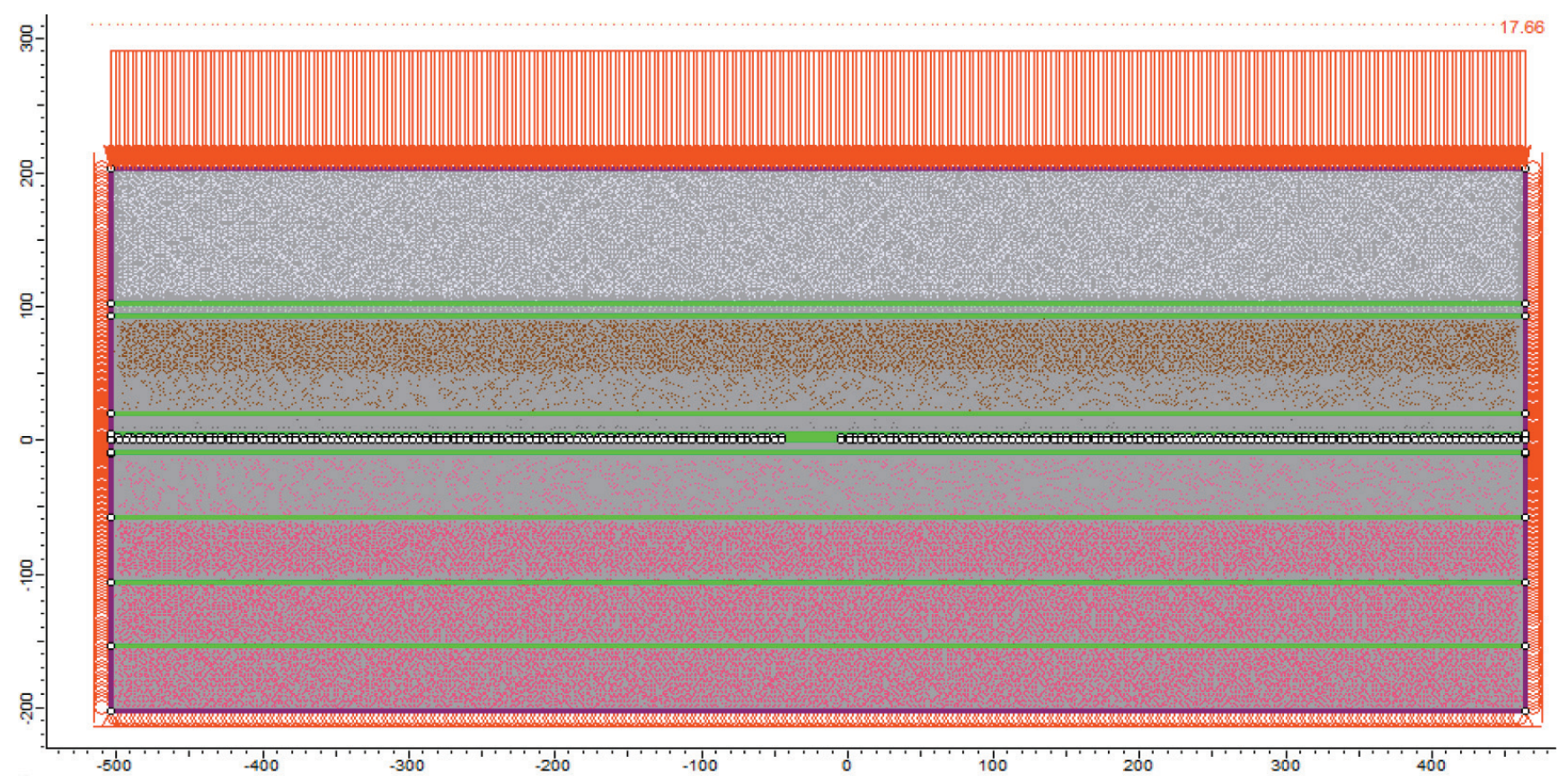

Fig. 3. Computational scheme for a remnant of $40 \mathrm{~m}$ in width 
(a)

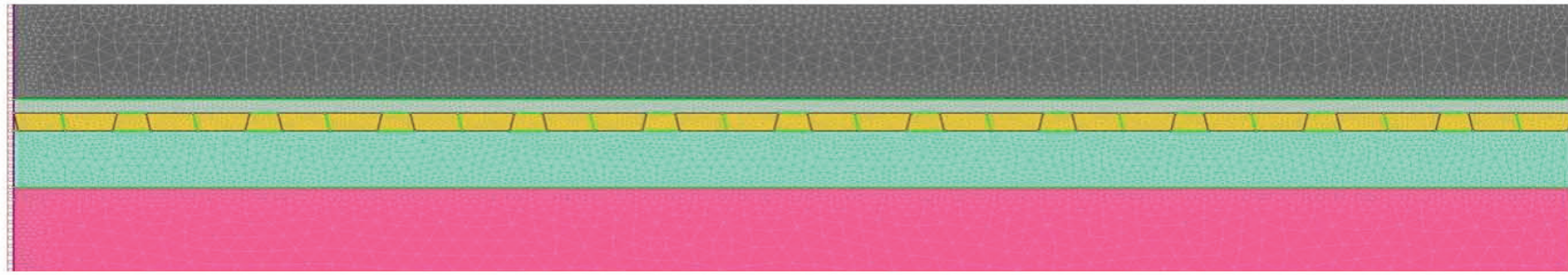

(b)

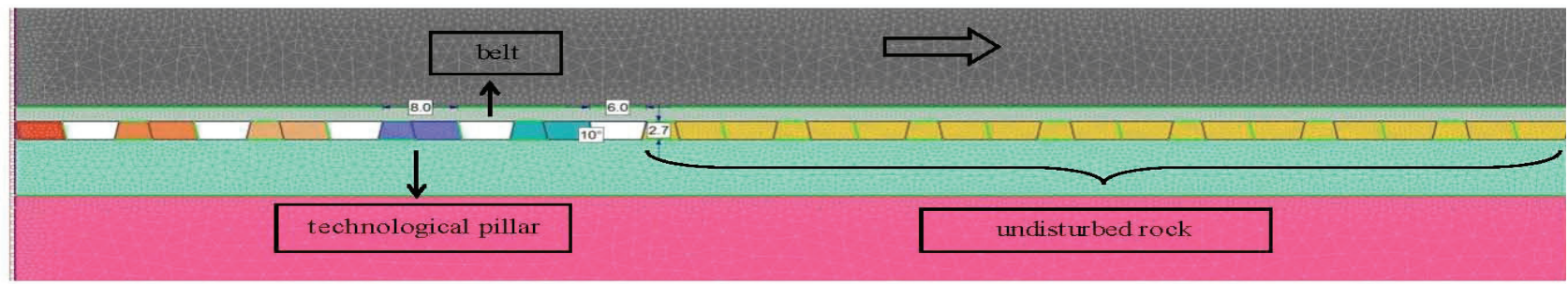

(c)

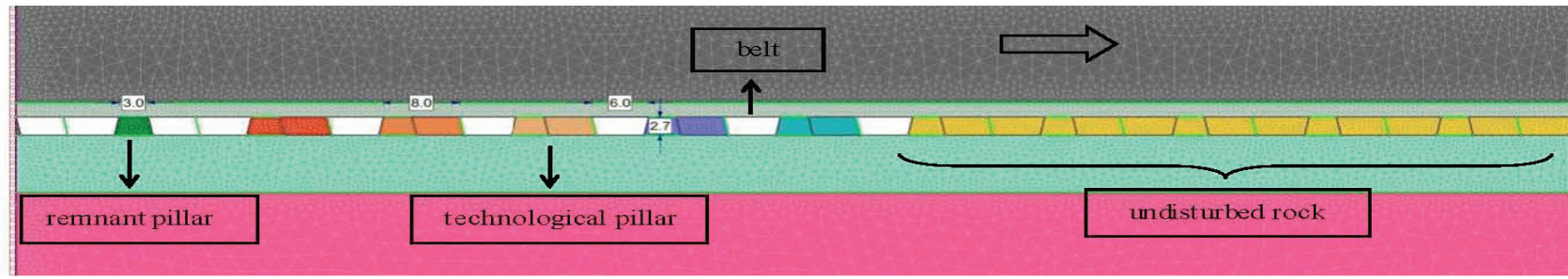

(d)

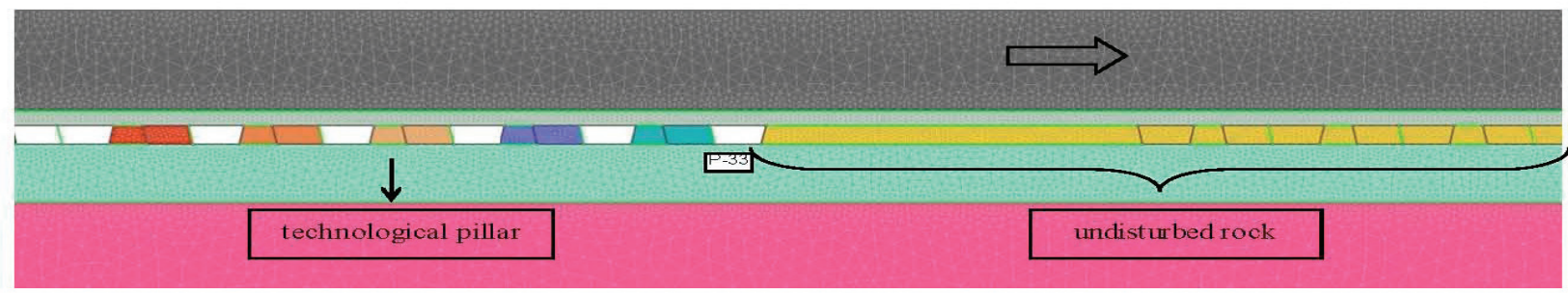

(e)

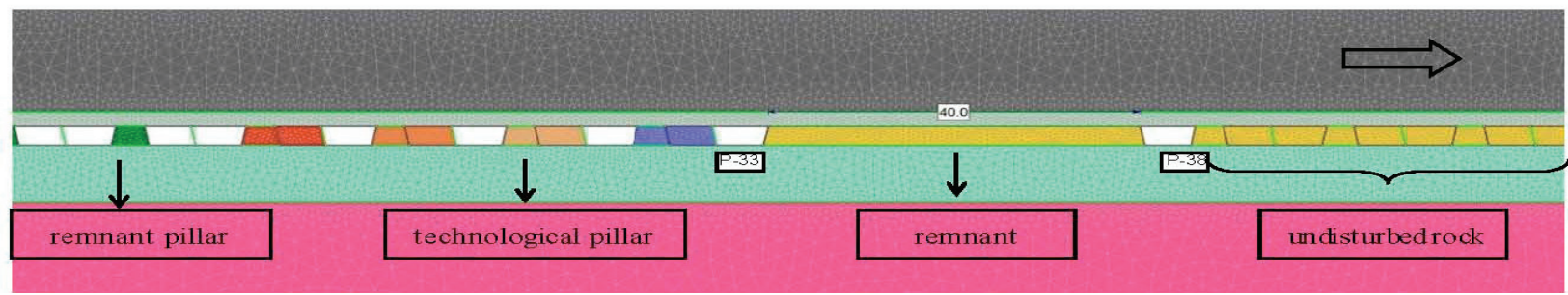

Fig. 4. Simulation of mining operations performed in the analyzed field: (a) step 1, (b) step 2, (c) step 4, (d) step 30, (e) step 31

Table 2. Geometry of the numerical model of the mining field being analyzed

\begin{tabular}{|c|c|c|c|c|c|c|}
\hline $\begin{array}{c}\text { Width of } \\
\text { technological } \\
\text { pillars } \\
{[\mathrm{m}]}\end{array}$ & $\begin{array}{c}\text { Width of } \\
\text { remnant } \\
\text { pillars } \\
{[\mathrm{m}]}\end{array}$ & $\begin{array}{c}\text { Height of } \\
\text { excavations }\end{array}$ & $\begin{array}{c}\text { Width } \\
\text { of belt } \\
{[\mathrm{m}]}\end{array}$ & $\begin{array}{c}\text { Angle } \\
\text { of inclination } \\
\text { of side walls } \\
{[\mathrm{m}]}\end{array}$ & $\begin{array}{c}\text { Width of } \\
\text { opening of } \\
\text { the work } \\
\text { space }\end{array}$ & $\begin{array}{c}\text { Width of } \\
\text { remnant }\end{array}$ \\
\hline 8 & 3 & 2.7 & 6 & 10 & 5 belts & 40 \\
\hline
\end{tabular}

first step covered the situation in the rock mass before excavation of mining headings (Fig. 4a). The second step involved cutting into undisturbed rock and formation of technological pillars with the dimensions presented in Table 2 (Fig. 4b). In the next steps, the size of technological pillars was reduced to remnant dimensions and successive technological pillars were formed (Fig. 4c). Working in the deposit was performed in belts 


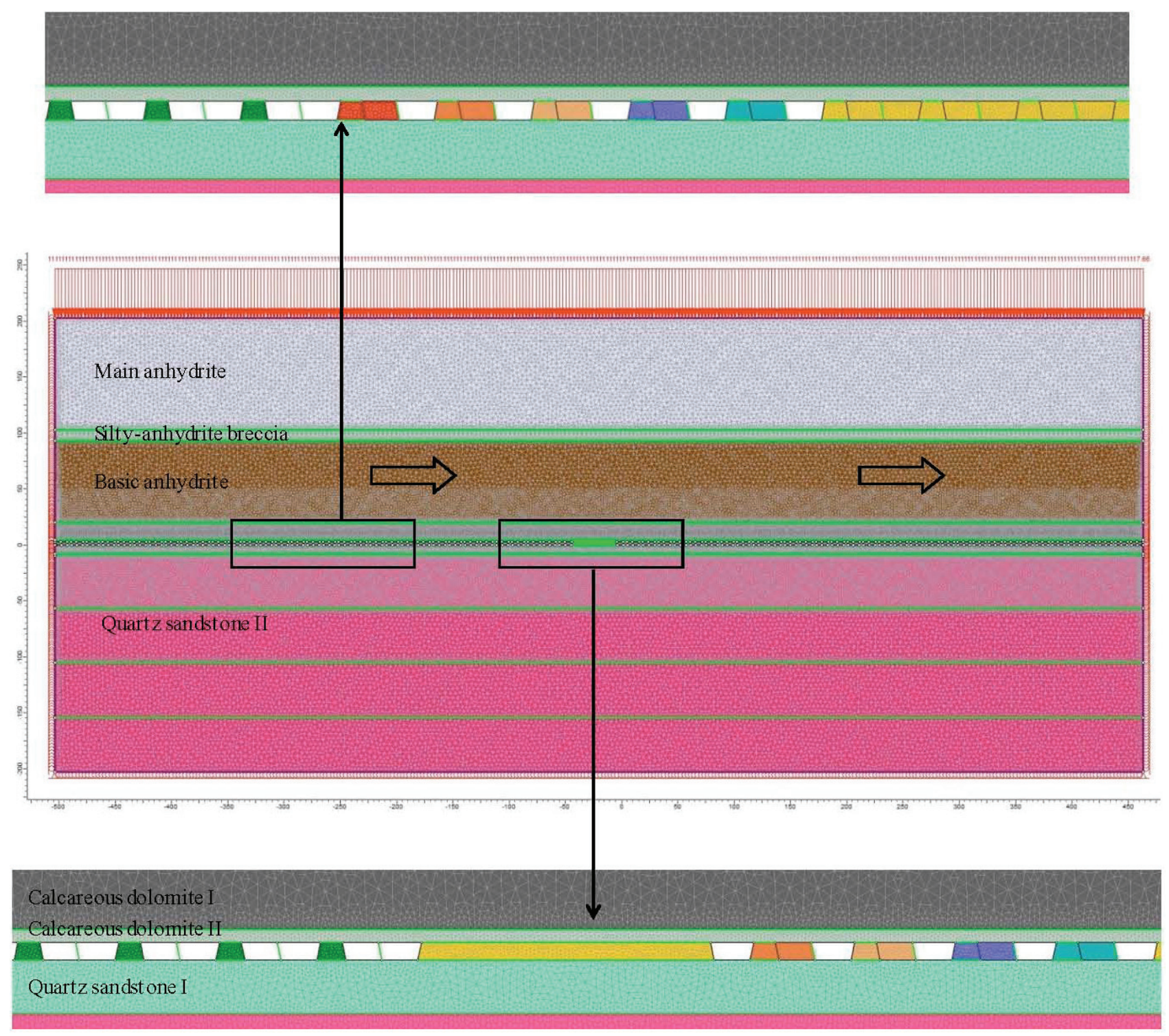

Fig. 5. Computational scheme for analyzed region (deposit remnant of $40 \mathrm{~m}$ in width)

with dimensions presented in Table 2. In numerical simulations, a width of opening of the workspace equal to 5 belts was accounted for. It was decided to separate the remnant when the length of the front amounted to approximately $460 \mathrm{~m}$ (computational step 30 in the numerical model) (Fig. 4d) by making belt P-38 outside of the area at risk (computational step 31) (Fig. 4e). The computational scheme is presented in Fig. 5.

\section{PARAMETERS OF ROCKS AND THE ROCK MASS ACCEPTED FOR NUMERICAL MODELING}

The parameters of rocks were determined for numerical analyses on the basis of results of laboratory tests conducted on rock samples collected from geological reconnaissance boreholes drilled in the region under consideration: S-294, Mo-12 To-2, Mo-12 To-5 and Mo-11 To-3. Average parameters of rocks determined in a laboratory are presented in Table 3. The parameters of the rock mass accepted for numerical modeling for the Coulomb-Mohr criterion were calculated by means of RocLab software on the basis of the Hoek-Brown classification and are presented in Table 4. Residual (post-destruction) values of the internal friction angle $\phi_{\text {res }}$ and cohesion $c_{\text {res }}$ were determined by using reducing coefficients (Bauer et al. [5]):

$$
\begin{gathered}
\phi_{\text {resid }}=0.95 \cdot \phi, \\
c_{\text {resid }}=(0.2 \div 0.3) \cdot c .
\end{gathered}
$$


Table 3. Average geomechanical parameters of rocks

\begin{tabular}{|l|l|c|c|c|c|c|c|c|}
\hline \multirow{3}{*}{ Location } & \multicolumn{1}{|c|}{ Name of rock } & $\begin{array}{c}h \\
{[\mathrm{~m}]}\end{array}$ & $\begin{array}{c}\rho \\
{\left[\mathrm{kg} / \mathrm{dm}^{3}\right]}\end{array}$ & $\begin{array}{c}R_{c} \\
{[\mathrm{MPa}]}\end{array}$ & $\begin{array}{c}R_{r} \\
{[\mathrm{MPa}]}\end{array}$ & $\begin{array}{c}E_{s} \\
{[\mathrm{MPa}]}\end{array}$ & $\begin{array}{c}v \\
{[-]}\end{array}$ & $\begin{array}{c}\text { Wet } \\
{[-]}\end{array}$ \\
\hline \multirow{4}{*}{ Roof } & Main anhydrite & 100.0 & 2.90 & 93.1 & 6.4 & 56100 & 0.24 & - \\
\cline { 2 - 9 } & Silty-anhydrite breccia & 10.0 & 2.25 & 36.0 & 1.7 & 13650 & 0.18 & - \\
\cline { 2 - 10 } & Basic anhydrite & 73.0 & 2.90 & 95.5 & 5.5 & 54600 & 0.25 & 3.11 \\
\cline { 2 - 10 } & Calcareous dolomite I & 15.0 & 2.53 & 132.5 & 8.3 & 51090 & 0.24 & 10.39 \\
\cline { 2 - 10 } & Calcareous dolomite II & 2.0 & 2.74 & 213.0 & 16.0 & 99,320 & 0.27 & 17.70 \\
\hline \multirow{2}{*}{ Mined deposit } & & 2.7 & 2.63 & 110.9 & 7.4 & 34450 & 0.21 & 3.42 \\
\hline \multirow{2}{*}{ Floor } & Quartz sandstone I & 8.2 & 2.12 & 22.1 & 1.4 & 8190 & 0.15 & 0.96 \\
\cline { 2 - 10 } & Quartz sandstone II & 194.5 & 1.95 & 16.7 & 0.7 & 6190 & 0.13 & 0.69 \\
\hline
\end{tabular}

Table 4. Parameters of rock mass accepted for numerical modeling in an elastic-plastic medium with softening

\begin{tabular}{|c|c|c|c|c|c|c|c|c|c|c|}
\hline Location & Name of rock & $\begin{array}{c}h \\
{[\mathrm{~m}]}\end{array}$ & $\begin{array}{c}E_{s} \\
{[\mathrm{MPa}]}\end{array}$ & $\begin{array}{c}v \\
{[-]}\end{array}$ & $\begin{array}{c}\sigma_{t} \\
{[\mathrm{MPa}]}\end{array}$ & $\begin{array}{c}c \\
{[\mathrm{MPa}]}\end{array}$ & $\begin{array}{c}\phi \\
{\left[{ }^{\circ}\right]}\end{array}$ & $\begin{array}{c}c_{r e s} \\
{[\mathrm{MPa}]}\end{array}$ & $\begin{array}{c}\phi_{\text {res }} \\
{\left[^{\circ}\right]}\end{array}$ & $\begin{array}{c}\delta \\
{\left[{ }^{\circ}\right]}\end{array}$ \\
\hline \multirow{5}{*}{ Roof } & Main anhydrite & 100.0 & 41110 & 0.24 & 0.75 & 6.97 & 38.66 & 1.39 & 36.73 & 2.00 \\
\hline & Silty-anhydrite breccia & 10.0 & 7100 & 0.18 & 0.09 & 2.51 & 39.06 & 0.50 & 37.11 & 2.00 \\
\hline & Basic anhydrite & 73.0 & 40010 & 0.25 & 0.77 & 7.15 & 38.66 & 1.43 & 36.73 & 2.00 \\
\hline & Calcareous dolomite I & 15.0 & 44980 & 0.24 & 2.93 & 12.09 & 39.00 & 2.42 & 37.05 & 2.00 \\
\hline & Calcareous dolomite II & 2.0 & 87440 & 0.27 & 4.72 & 19.90 & 39.00 & 3.98 & 37.05 & 2.00 \\
\hline Mined deposit & & 2.7 & 25240 & 0.21 & 0.83 & 8.42 & 39.31 & 1.35 & 37.35 & 2.00 \\
\hline \multirow{2}{*}{ Floor } & Quartz sandstone I & 8.2 & 4260 & 0.15 & 0.06 & 1.54 & 39.06 & - & - & - \\
\hline & Quartz sandstone II & 194.5 & 3220 & 0.13 & 0.04 & 1.16 & 39.06 & - & - & - \\
\hline
\end{tabular}

The following symbols are used in the tables above: $h$ - thickness of rock layers, $\rho$ - bulk density, $R_{c}-$ uniaxial compression strength of rock sample, $R_{r}$ - tensile strength of rock sample, $E_{s}$ - coefficient of direct elasticity, $v-$ Poisson's ratio, $\sigma_{t}-$ tensile strength of rock mass, $c$ - coefficient of cohesion, $\phi$ - internal friction angle, $\delta$ - angle of dilatancy, $c_{\text {res }}-$ residual coefficient of cohesion, $\phi_{\text {res }}-$ residual internal friction angle.

In LGOM mines, according to accepted rockburst prophylactics, efforts are made for technological pillars to continue working in a post-destruction state. In the numerical model, increased pillar pliancy was simulated by reducing their strength and deformation parameters. In order to represent reality in the analyzed field as closely as possible, reduced parameter values were selected iteratively in such a manner that the numerically calculated convergence values were as close as possible to the results of convergence measurements performed in underground conditions (Adach [3]).

\section{ANALYSIS OF THE RESULTS OF NUMERICAL CALCULATIONS}

Evaluation of the influence of a remnant of $40 \mathrm{~m}$ in width on the occurrence of seismic phenomena in the mining field with a room-and-pillar system with roof deflection was conducted on the basis of vertical stress $\sigma_{y}$ distribution and the reach of areas of yielded elements. The behavior of the remnant and effort of the rock mass in its vicinity were analyzed in successive steps of simulated mining according to the roomand-pillar system with roof deflection.

By analyzing area of yielded elements, it can be observed that their reach grows in successive steps of simulated operation, particularly above mined out area (in gobs) (Fig. 6a-d). This indicates progressing disintegration of roof layers above gobs. The extent of the destroyed zone above mining headings amounts to approximately $2.0-2.5 \mathrm{~m}$.

The results of numerical simulations conducted for the room-and-pillar system with roof deflection showed that sudden fracturing and collapse of rigid roof layers above mined out areas may occur on the edge of the remnant, which may cause a shock with very high energy, potentially causing the rockburst phenomenon under the appropriate conditions. The results of calculations indicate that, in the course of reconstruction of the mining front, in computational step 35, when its distance is $560 \mathrm{~m}$ (approximation $60 \mathrm{~m}$ from the edge of the remnant) a yielded zone suddenly (in one computational step) forms in the roof above the edge of the remnant of $40 \mathrm{~m}$ in width (Fig. 6c). A transverse line of destruction in the roof forms 


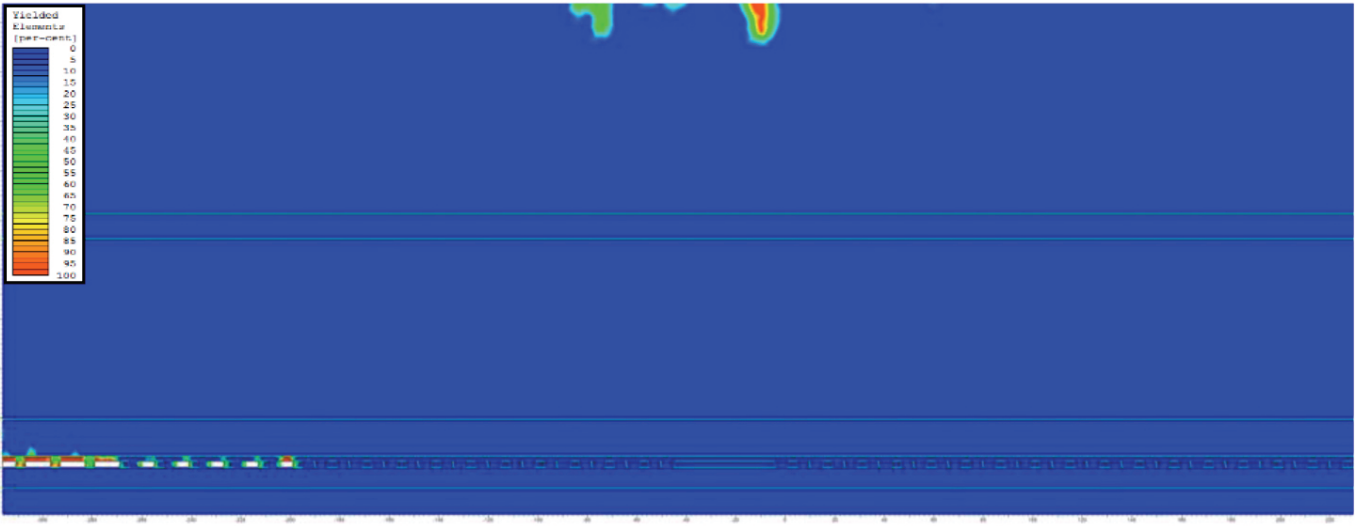

(a)

(b)
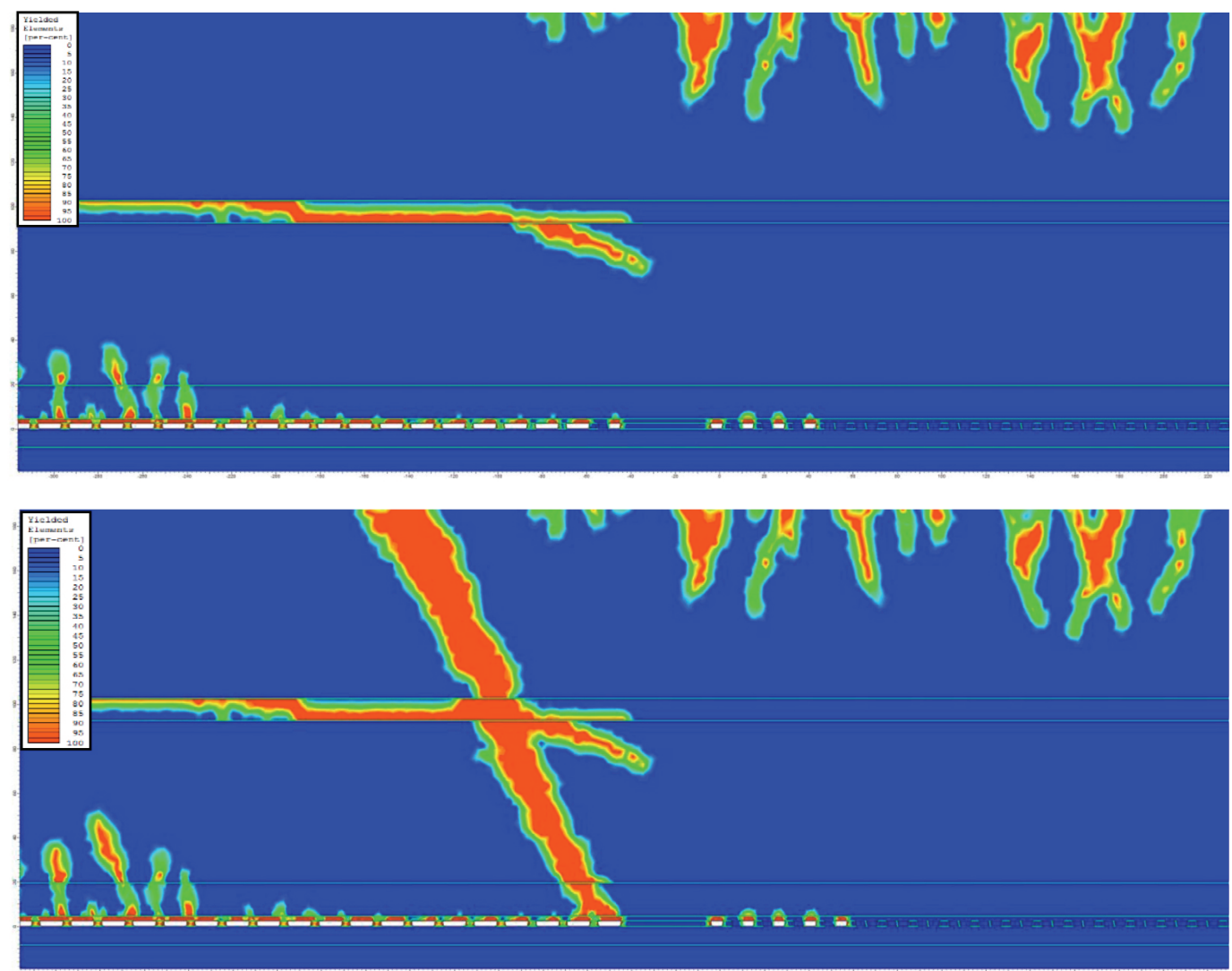

(c)

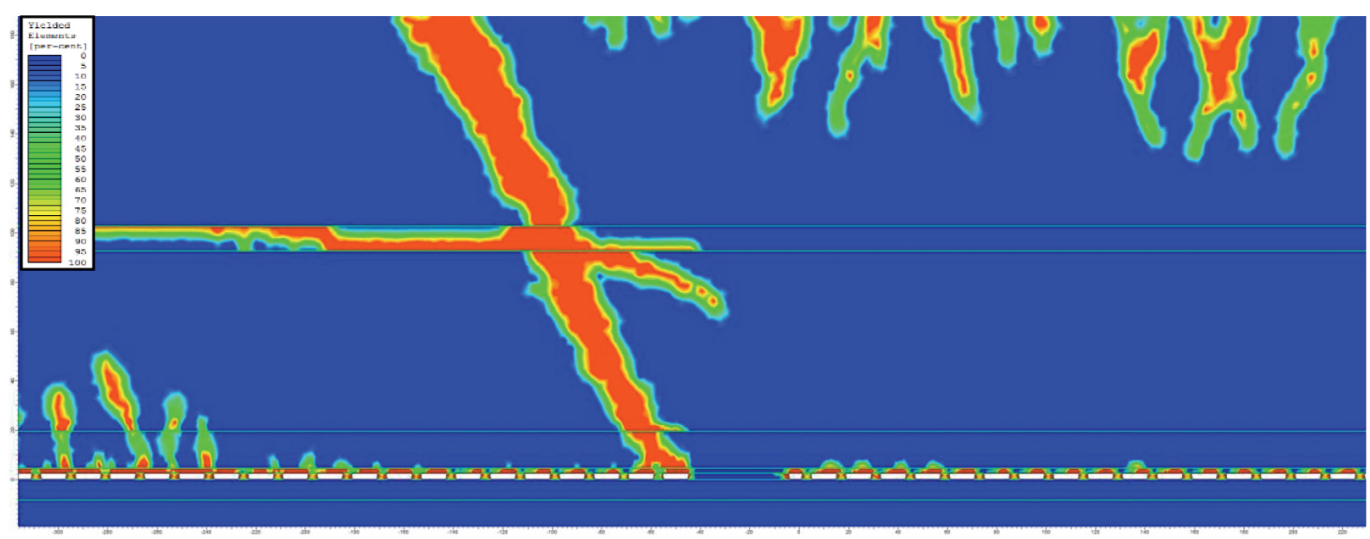

Fig. 6. The extent of yielded zones for front distance: (a) $300 \mathrm{~m}$ - computational step 19,

(b) $550 \mathrm{~m}$ (approx. $50 \mathrm{~m}$. from remnant edge) - computational step 34,

(c) $560 \mathrm{~m}$ (approx. $60 \mathrm{~m}$ from remnant edge) - computational step 35,

(d) $900 \mathrm{~m}$ (approx. $400 \mathrm{~m}$ from remnant edge) - computational step 59 


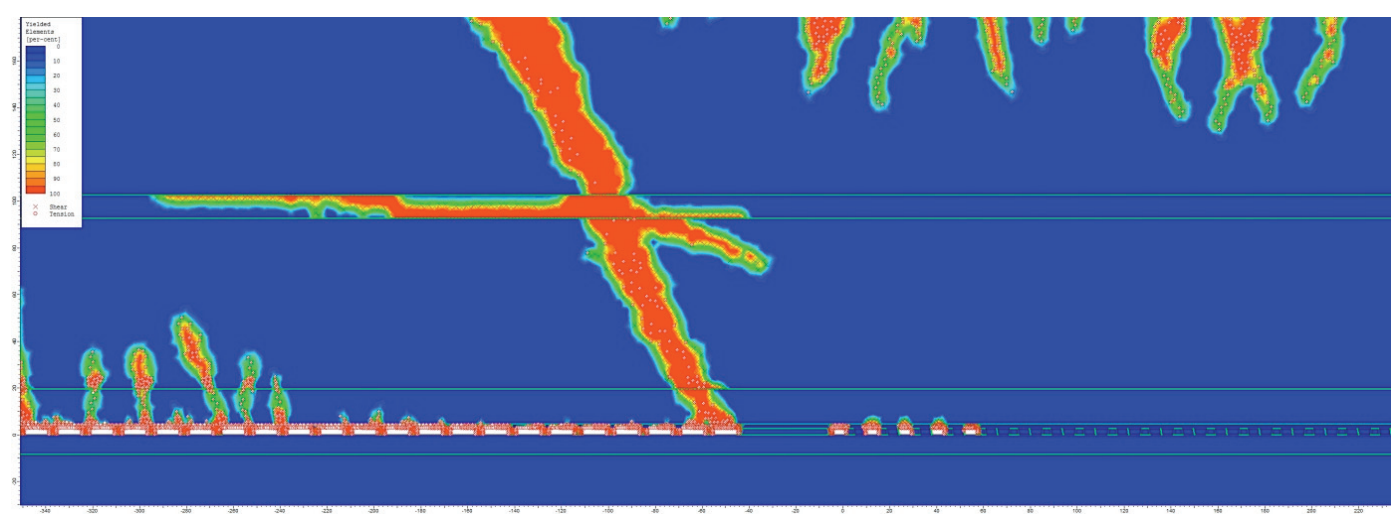

Fig. 7. The extent of yielded zones and destruction mechanism for front distance of $560 \mathrm{~m}$ (approx. $60 \mathrm{~m}$ from remnant edge) - computational step 35

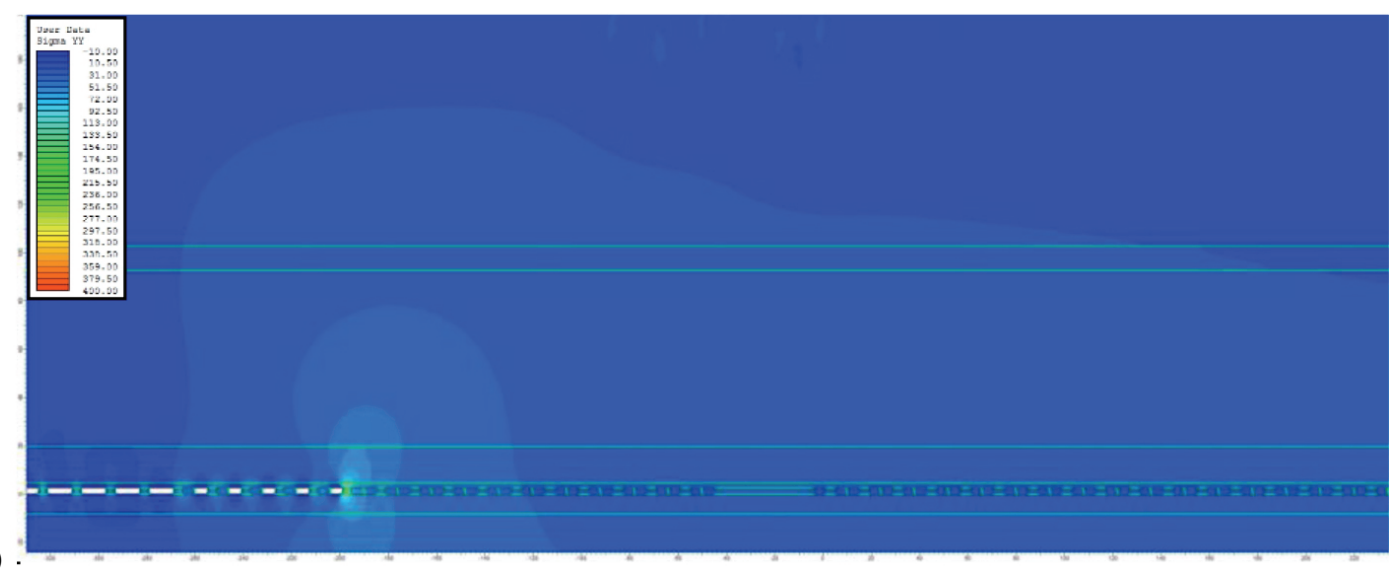

(a)

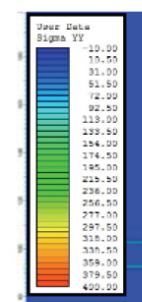

(b)
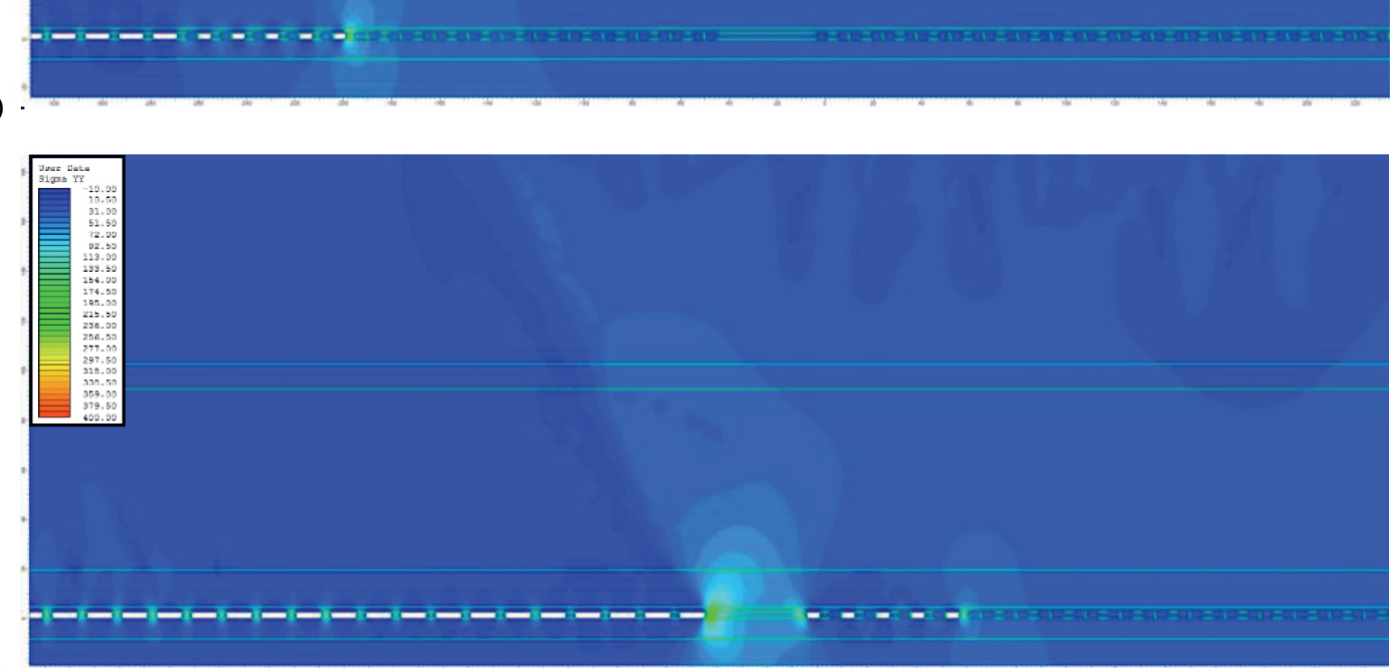

(c) 
(d)

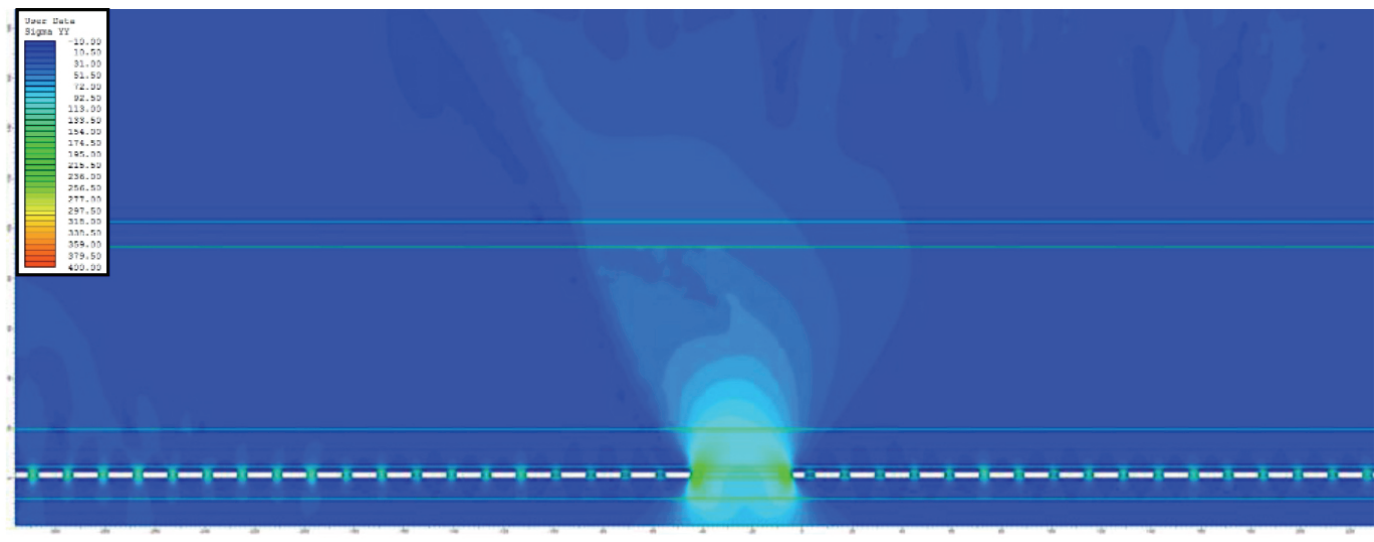

Fig. 8. Distribution of vertical stresses $\sigma_{y}$ for front distance: (a) $300 \mathrm{~m}$ - computational step 19,

(b) $550 \mathrm{~m}$ (approx. 50 from remnant edge) - computational step 34 ,

(c) $560 \mathrm{~m}$ (approx. $60 \mathrm{~m}$ from remnant edge) - computational step 35 ,

(d) $900 \mathrm{~m}$ (approx. $400 \mathrm{~m}$ from remnant edge) - computational step 59

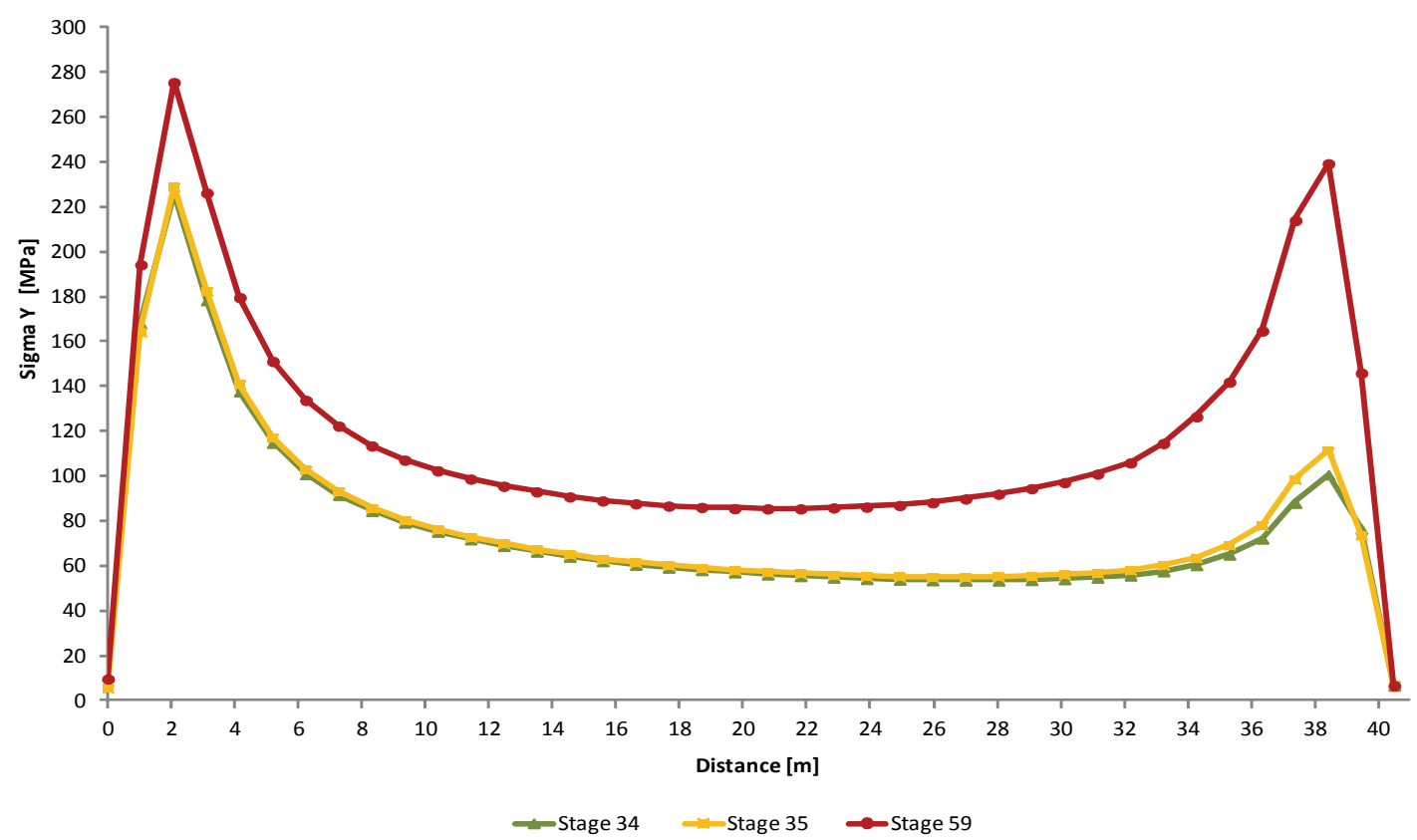

Fig. 9. Vertical stresses $\sigma_{y}$ inside the 40-m-wide remnant for front distance:

$550 \mathrm{~m}$ (approx. $50 \mathrm{~m}$ from remnant edge) - computational step 34, $560 \mathrm{~m}$ (approx. $60 \mathrm{~m}$ from remnant edge) - computational step 35, $900 \mathrm{~m}$ (approx. $400 \mathrm{~m}$ from remnant edge) - computational step 59

near the left edge of the remnant, being is inclined at an angle of approximately $60^{\circ}$ in the direction of the mined out area (gobs). It formed as upon exceeding the shear strength, above all (Fig. 7).

By analyzing the map of vertical stresses $\sigma_{y}$ in successive steps of operation (Fig. 8a-d), it can be observed that, before the remnant is left behind, the stress concentration zone was present in front of the advancing operational front, and separation of a rigid remnant disrupted the geomechanical situation in the mining area. The remnant became a place where stresses were concentrated, acting on rock strata in both the roof and the floor found in its vicinity.
Elevated stress zones are distributed centrally from the remnant in the roof and floor, and the extent of the action of the remnant and the value of stresses in its surroundings grow in successive steps of simulated mining as the front advances. As the distance from the remnant grows, its action decreases and vertical stress values tend towards the initial state. The occurrence of sudden destruction in the roof above the remnant edge (in computational step 35) disrupted the distribution of vertical stresses $\sigma_{y}$ near the left edge of the remnant and reduced the value of vertical stresses $\sigma_{y}$ in the area of the yielded zone (Fig. 8d). 
(a)

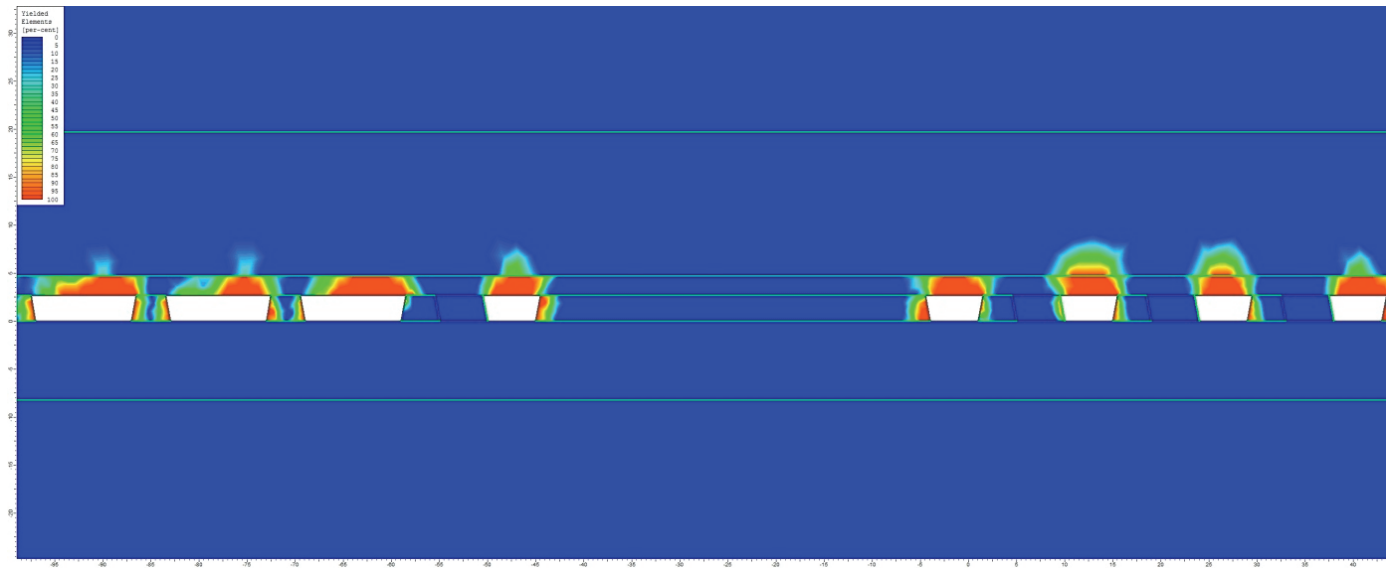

(b)
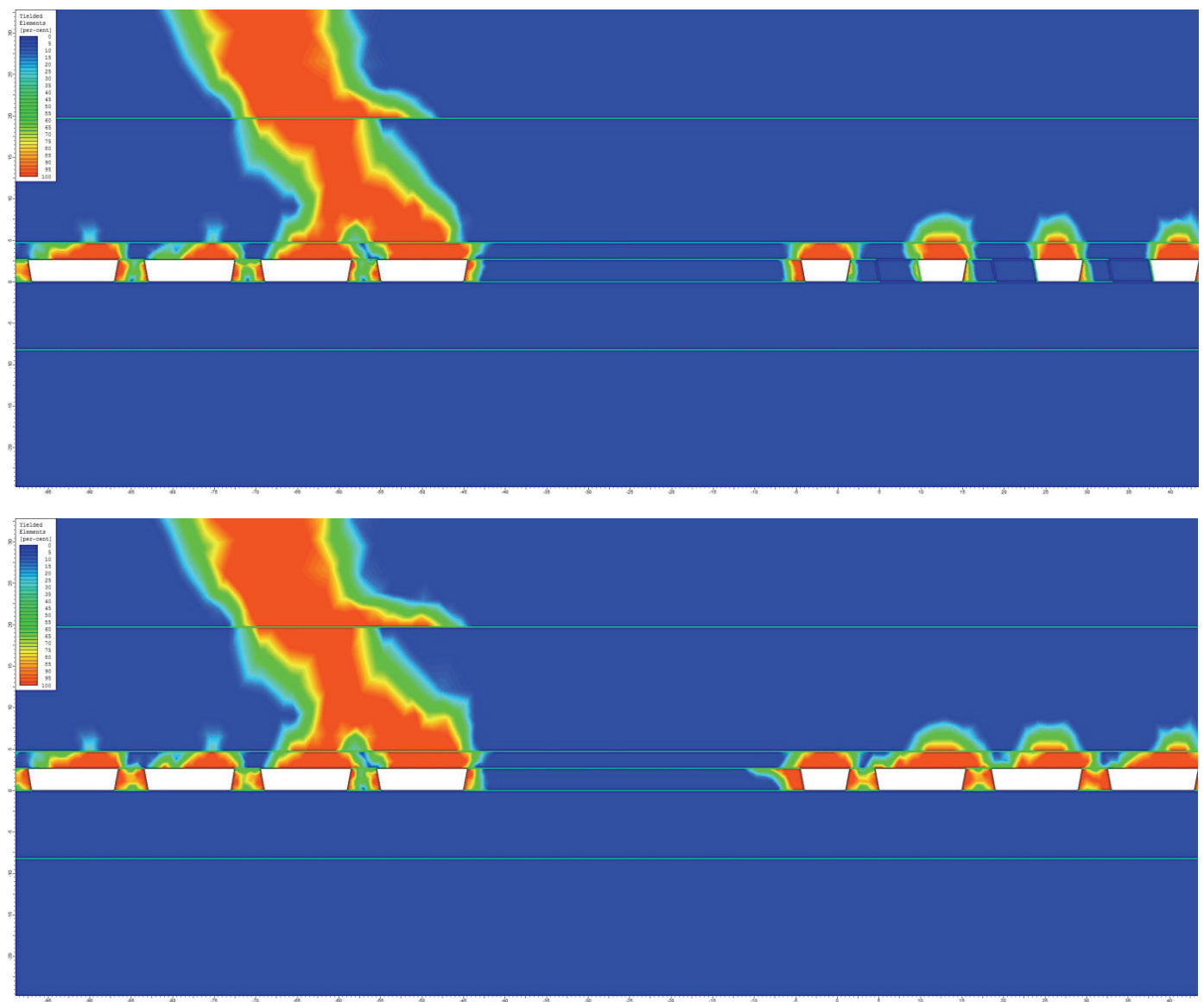

Fig. 10. Extent of yielded zones inside the deposit remnant of $40 \mathrm{~m}$ in width for front distance:

$550 \mathrm{~m}$ (approx. $50 \mathrm{~m}$ from remnant edge) - computational step 34, $560 \mathrm{~m}$ (approx. $60 \mathrm{~m}$ from remnant edge) - computational step 35, $900 \mathrm{~m}$ (approx. $400 \mathrm{~m}$ from remnant edge) - computational step 59

Inside the remnant, vertical stresses $\sigma_{y}$ reach the greatest values at a distance of approximately $2 \mathrm{~m}$ from its edge, and their value decreases towards the direction of the remnant center. The maximum values of these stresses occur near the left edge of the remnant, from the side of old workings. For a front distance of $550 \mathrm{~m}$ (approximately $50 \mathrm{~m}$ from the remnant edge - computational step 34), $560 \mathrm{~m}$ (approximately $60 \mathrm{~m}$ from remnant edge - computational step 35) and $900 \mathrm{~m}$ (approximately $400 \mathrm{~m}$ from remnant edge
- computational step 59), these values are equal to $226 \mathrm{MPa}$ (front distance $550 \mathrm{~m}$ ), $229 \mathrm{MPa}$ (front distance $560 \mathrm{~m}$ ) and $275 \mathrm{MPa}$ (front distance $900 \mathrm{~m}$ ), respectively. Inside the remnant, vertical stresses $\sigma_{y}$ for analogous front lengths are equal to approximately $55 \mathrm{MPa}$ (front distance $550 \mathrm{~m}$ ), $57 \mathrm{MPa}$ (front distance $560 \mathrm{~m}$ ) and $85 \mathrm{MPa}$ (front distance $900 \mathrm{~m}$ ), respectively (Fig. 9). Vertical stress $\sigma_{y}$ values near edges and inside of the remnant grow in successive steps of operation. 
The results of numerical simulations demonstrated that yielded areas inside the remnant with a width of $40 \mathrm{~m}$, left behind in the analyzed mining field, occur only near its edges, and their reach increases in successive steps of mining (Fig. 10a-c). For a front length of $900 \mathrm{~m}$ (approximately $400 \mathrm{~m}$ from the remnant edge), the reach of yielded areas reaches a maximum of approximately $3.5 \mathrm{~m}$. This indicates that strength is exceeded on the edges of the remnant and destroyed zones are formed, while its internal part remains stable. In the analyzed mining field, after the occurrence of the phenomenon of roof layers' collapse above the remnant edge, the internal part of the remnant remained stable (Fig. 10b).

\section{SUMMARY}

The great advancement of mining operations in copper ore mines in the Legnica-Głogów Copper District caused mining works to be performed under increasingly difficult geological and mining conditions that occur more and more frequently, including the area of action of remnants. Experiences in global and Polish underground mining indicate that remnants that are left behind may have an influence on the occurrence of seismic phenomena. This is why the problem of deposit mining in the vicinity of remnants' action is of major importance to the safety of works. Remnants pose a threat due to both the possibility of a stress-induced rockburst and their potential to cause collapse of strong roof layers above their edges, which may result in the generation of high-energy shocks.

The results of numerical simulations conducted for one of the fields mined according to the roomand-pillar system showed that a remnant that is left behind is a site of stress concentration and acts on layers in the roof and floor located in its vicinity. The reach of the action of a part of remnant that is left behind and stress values in its vicinity grow significantly in successive steps of simulated mining as the front advances. Numerical computations for an elastic-plastic model with softening showed that the greatest values of vertical stresses $\sigma_{y}$ inside the remnant being analysed with a width of $40 \mathrm{~m}$ occur near its edges, while in the central part of the remnant, vertical stresses $\sigma_{y}$ do not exceed the value of approximately $85 \mathrm{MPa}$, even when the mining front is found at a significant distance from its edge (approximately $400 \mathrm{~m}$ ). The results of numerical modeling also indicate that a remnant of $40 \mathrm{~m}$ in width and of $2.7 \mathrm{~m}$ in height left behind in the analyzed mining field should be stable even in the case of significant advancement of mining operations and should not pose a threat of stress-induced rockburst. Only side wall zones may be destroyed. However, numerical simulations also showed that sudden roof fracturing may occur during restoration of the operational front on the edge of a rigid remnant, from the side of gobs, leading to a high-energy shock as a result of exceedance of shear strength. The core of the remnant remained intact.

\section{ACKNOWLEDGEMENT}

This study was conducted thanks to statutory funds no. 04010207/16 granted to the Faculty of Geoengineering, Mining and Geology of the Wrocław University of Science and Technology.

\section{REFERENCES}

[1] ADACH K., Ocena wptywu pozostawionej resztki złoża na stan naprężen w polu eksploatacyjnym (Evaluation of the influence of a deposit remnant on the stress state in an excavation zone), Interdyscyplinarne zagadnienia $w$ górnictwie $i$ geologii (Interdisciplinary problems in mining and geology), Vol. IV, Wrocław 2013, (in Polish).

[2] ADACH K., Analiza aktywności sejsmicznej i wyników tomografii pasywnej $w$ wybranym polu eksploatacyjnym kopalń rud miedzi LGOM (Analysis of seismic activity and results of passive tomography in a selected mining field of copper ore mines in LGOM), Interdyscyplinarne zagadnienia $w$ górnictwie $i$ geologii (Interdisciplinary problems in mining and geology), Vol. V, Wrocław 2014, (in Polish).

[3] ADACH K., Wpływ wielkości pozostawionych resztek złoża na zagrożenie sejsmiczne i tapaniami $w$ kopalniach LGOM (Influence of the size of remnants on seismic and rockburst risks in LGOM mines), Doctorate thesis (unpublished work), Wrocław University of Science and Technology, Wrocław 2015, (in Polish).

[4] ADACH K., ButRa J., Ocena wptywu pozostawionej resztki złoża na sytuację geomechaniczna $w$ polu eksploatacyjnym $w$ świetle modelowania numerycznego (Evaluation of the influence of a deposit remnant on the geomechanical situation in an mining field by numerical modeling), Rudy i Metale Nieżelazne Non-ferrous Ores and Metals, 2015, No. 5, (in Polish).

[5] BAuer J., Bilikowski M., Butra J., Debkowski R., WróBel J., Wyznaczanie szerokości filarów technologicznych $w$ kopalniach rud miedzi $z$ wykorzystaniem MES, $w$ aspekcie stateczności stropu wyrobisk eksploatacyjnych (Determination of the width of technological pillars in copper ore mines using FEM, from the perspective of the roof stability of excavation headings), Prace Naukowe Instytutu Geotechniki i Hydrotechniki Politechniki Wrocławskiej (Scientific Works of the Institute of Geotechnology and Hydrotechnology of the Wrocław University of Science and Technology), 2001, No. 73, Conferences, No. 40, (in Polish). 
[6] Burtan Z., Chlebowski D., Poziom zagrożenia sejsmicznego $w$ kopalniach wegla kamiennego a prowadzenie eksploatacji $w$ warunkach skrępowanych (Level of seismic risk in hard coal mines and performance of excavation under constrained conditions), Mechanizacja i Automatyzacja Górnictwa (Mechanization and Automation of Mining), 2007, No. 9 (440), (in Polish).

[7] BUTRA et al., Analiza wplywu pozostawienia w plaszczyznach eksploatacji stref kamiennych o różnych gabarytach na stan zagrożenia przejawami ciśnienia górotworu (Analysis of the influence of leaving rock zones of various dimensions in excavation planes on the risk of manifestations of rock mass pressure), Zakład Usług Geologiczno-Górniczych (Geological and Mining Services Center) (unpublished work), Wrocław 1992, (in Polish).

[8] Butra J., PYtel W., Eksploatacja złoża zagrożonego tapaniami $w$ świetle modelowania numerycznego (Excavation of a deposit at risk of rockbursts in the light of numerical modeling), Rudy i Metale Nieżelazne (Non-ferrous Ores and Metals), 2008, No. 2, (in Polish).

[9] ButRA J., Eksploatacja złoża rud miedzi w warunkach zagrożenia tapaniami $i$ zawatami (Excavation of a copper ore deposit under conditions of rockburst and rockfall risk), Wydawnictwo KGHM CUPRUM Centrum Badawczo-Rozwojowe (Publishing House of KGHM CUPRUM Research and Development Center), Wrocław 2010, (in Polish).

[10] Butra J., DęBKowski R., IwUlski Z., SzPak M., Analiza dokonanej eksploatacji oraz sposobu dalszego prowadzenia robót eksploatacyjnych $w$ polu G-7/5 O/ZG „RUDNA” (Analysis of completed mining and method of further performance of mining works in G-7/5 "RUDNA" Mining Field), Górnictwo i Geoinżynieria (Mining and Geoengineering), 2011, Vol. 35, Book 2. Cracow, (in Polish).

[11] Butra J., ADACH K., Weryfikacja za pomoca metody elementów skończonych analitycznego sposobu wyznaczania naprężeń w sąsiedztwie pozostawionej resztki złoża (Finite Element Method verification of an analytical method of determining stresses in the vicinity of a deposit remnant), Czasopismo Naukowo-Techniczne Górnictwa Rud "Cuprum" ("Cuprum" Scientific and Technical Journal of Ore Mining), 2014, No. 1 (70). Wrocław, (in Polish).

[12] Chlebowski D., Zorychta A., Burtan Z., Skrepowane warunki geologiczno-górnicze istotnym czynnikiem wplywajacym na wielkość zagrożenia tapaniami w polskim górnictwie węgla kamiennego (Constrained geological and mining conditions a significant factor affecting the magnitude of rockburst risk in Polish hard coal mining), Materials of International Conference: Mining and Geology after joining the European Union, Demanowska Dolina 2004, (in Polish).

[13] CHUDEK M., Mechanika górotworu z podstawami zarządzania ochrona środowiska $w$ obszarach górniczych i pogórniczych (Rock mass mechanics and basics of environmental protection management in mining and post-mining areas), Wydawnictwo Politechniki Gliwickiej, Gliwice 2010, (in Polish).

[14] DĘBKOwSKI R. et al., Uwarunkowania geomechaniczne eksploatacji złoża $w$ sasiedztwie zrobów $i$ stref upodatnionych, $w$ aspekcie możliwości stosowania istniejacych lub nowych sposobów eksploatacji (Geomechanical conditions of deposit mining in the vicinity of workings and zones with increased pliancy, from the perspective of the possibility of applying existing or new mining methods) (unpublished work), KGHM Cuprum sp. z.o.o., Wrocław 2007, (in Polish).
[15] DrZęźla B., Mendecki A., Marcela E., Wplyw warunków górniczych na ksztaltowanie się aktywności sejsmicznej na przyktadzie KWK Miechowice (Influence of mining conditions on seismic activity on the example of Miechowice hard coal mine), Publs. Inst. Geophys. Pol. Acad. Sc., 1984, M-6 (176), 377-383, (in Polish).

[16] Durrheim R.J., Haile A., Roberts M.K.C., Hagan T.O., JaGER A.J., HANDLEy M.F., SPOTTISWOODE S.M., ORTLEPP W.D., Factors influencing the severity of rockburst damage in South African gold mines.

[17] DurRheim R.J., HAILE A., RoberTs M.K.C., SCHWEITZER J.K., SPOTTISWOOdE S.M., KLOKOW J.W., Violent failure of a remnant in a deep South African gold mine, Tectonophysics, 1998a, 289, South Africa.

[18] Dyczko A., Kopacz M., Stopkowicz A., Wplyw występowania stref kamiennych na efektywność ekonomiczna eksploatacji złoża $w$ warunkach polskich kopalń rud miedzi (Influence of the presence of rock zones on the economic effectiveness of deposit mining under the conditions in Polish copper ore mines), Górnictwo i Geoinżynieria (Mining and Geoengineering), 2010, Vol. 34, Book 3, Cracow, (in Polish).

[19] Goszcz A., Elementy mechaniki skat oraz tapania w polskich kopalniach węgla i miedzi (Elements of rock and rockburst mechanics in Polish coal and copper mines), IGSMiE PAN Publishing House, Cracow 1999, (in Polish).

[20] Goszcz A., Wybrane problemy zagrożenia sejsmicznego i zagrożenia tapaniami $w$ kopalniach podziemnych (Selected problems of seismic and rockburst risk in underground mines), Publishing House of the Library of the School of Underground Mining, Cracow 2004, (in Polish).

[21] KŁeczek Z., Zorychta A., Chlebowski D., Etryk W., KRZYŻOWSKI A., Wpływ zaszłości eksploatacyjnych i zaburzeń tektonicznych na możliwość wystapienia tapnięcia (na przyktadzie tapnięcia $w$ KWK ,Pokój” $w$ dniu 27.07.2006 r.) (Influence of mining events and tectonic disruptions on the possibility of rockburst occurrence (on the example of the rockburst in the "Pokoj" hard coal mine on 27/07/2006)). Prace Naukowe - Monografie/CMG KOMAG Scientific Works (Monographs/CMG KOMAG), Gliwice 2007, (in Polish).

[22] LEACH A.R., LENHARDT W.A., Pillar associated seismicity at Western Deep Levels Mine. Static and Dynamic considerations in Rock Engineering, Brummer (ed.), Balkema, Rotterdam 1990.

[23] Lenhardt W.A., Hagan T.O., Observations and possible mechanisms of pillar associated seismicity at great depth, International Deep Mining Conference, Johannesburg, South Africa, SAIMM, Symposium Series S10, 1990, 1183-1194.

[24] LenhardT W.A., Seismicity associated with deep-level mining at Western Deep Levels Limited, Journ. South Afr. Inst. Min. Metall., 1992, Vol. 92, No. 5, 113-120.

[25] LE Roux P.J., The Extraction of Existing Remnant Blocks of Ground at Harmony Gold Mine's Free State Operations, Research Report, Faculty of Engineering and the Built Environment, University of the Witwatersrand, Johannesburg 2008.

[26] Le RouX P.J., STACEY T.R., Establishing a methodology for the assessment of remnant stability using recorded seismic events on Harmony mines, SHIRMS. Australian Centre for Geomechanics, Perth 2008.

[27] NAWRAT S., JAKUBÓw A., Zagrożenie tapaniami $w$ kopalniach Jastrzębskiej Spótki Węglowej (Rockburst risk in mines of Jastrzębska Spótka Węglowa), Przegląd Górniczy (Mining Review), 1997, No. 7, (in Polish). 
[28] PARYSIEWICZ W., Tapania w kopalniach (Rockbursts in mines), Wyd. Śląsk (Silesian Publishing House), Katowice 1966, (in Polish).

[29] Salustowicz A., Ciśnienie w pozostawionych resztkach poktadów (Pressure in deposit remnants), Zeszyty Naukowe AGH (Scientific Journals of AGH), No. 2, Publishing House PWN (Polish Scientific Publishers), Cracow 1954, (in Polish).

[30] SAŁustowicz A., Mechanika górotworu (Rock mass mechanics), Wydawnictwo Górniczo-Hutnicze (Mining and Metallurgy Publishing House, Stalinogród 1955, (in Polish).
[31] SAŁustowicz A., Zarys mechaniki górotworu (An outline of rock mass mechanics), Wydawnictwo Śląsk (Silesian Publishing House), Katowice 1968, (in Polish).

[32] SetlaK K., GoŁda A., MoszKo M., Zaszlości eksploatacyjne jako czynnik ksztattowania aktywności sejsmicznej górotworu na przyktadzie eksploatacji poktadu 207 w bloku E w OG „Lędziny I" (Mining events as a factor shaping seismic activity of rock mass on the example of mining of bed 207 in block E at "Lędziny I" Mining Center), Górnictwo (Mining). Publishing House of AGH 2010, (in Polish). 